\title{
Hydrazinyldiene-chroman-2,4-diones in inducing growth arrest and apoptosis in breast cancer cells: Synergism with doxorubicin and correlation with physicochemical properties
}

\author{
LULZIME BALLAZHI ${ }^{1}$ \\ FAIK IMERI ${ }^{2}$ \\ AHMED JASHARI ${ }^{3}$ \\ EMIL POPOVSKI ${ }^{4}$ \\ GORAN STOJKOVIĆ 4 \\ ALEKSANDAR J. DIMOVSKI ${ }^{1}$ \\ BOZHANA MIKHOVA ${ }^{5}$ \\ KRISTINA MLADENOVSKA ${ }^{1, *}$ \\ ${ }^{1}$ Faculty of Pharmacy, Center of Biomolecular \\ Pharmaceutical Analyses \\ University "Ss Cyril and Methodius" \\ 1000 Skopje, Republic of Macedonia \\ ${ }^{2}$ Institute of Physiology, University \\ of Zürich, CH-8057, Zürich, Switzerland \\ ${ }^{3}$ Faculty of Natural Sciences $\mathcal{E}$ Mathematics \\ State University of Tetovo, 1200 Tetovo \\ Republic of Macedonia \\ ${ }^{4}$ Institute of Chemistry, Faculty of Natural \\ Sciences and Mathematics, University \\ "Ss. Cyril and Methodius", PO Box 162 \\ 1000 Skopje, Republic of Macedonia \\ ${ }^{5}$ Bulgarian Academy of Sciences \\ Institute of Organic Chemistry with Centre \\ of Phytochemistry, 1113 Sofia, Bulgaria
}

\begin{abstract}
This study evaluates the effects of previously synthesized hydrazinyldiene-chroman-2,4-diones on cell proliferation and apoptosis, cell cycle distribution and migration capacity of MCF-7 breast cancer cells in synergy with doxorubicin. Physicochemical properties of the synthesized compounds were correlated with their structure and activity. Significant cell viability decrease in comparison with the effect of doxorubicin alone and the reference 4-hydroxycoumarin was observed when combination treatment comprising doxorubicin and the title compounds was applied. Synergistic effect with doxorubicin was also observed in down-regulation of phospho-Thr ${ }^{308} \mathrm{Akt}$ levels, confirming reduced proliferation and increased apoptosis. Combined treatment increased the percentage of cells arrested at the $\mathrm{G}_{2} / \mathrm{M}$ stage. Additive inhibition of cell migration was also observed, pointing to the possibility of reducing the risk of metastases. With their solubility profile and $\log D_{7.4}$, all the synthesized compounds follow Lipinski's rule of five for good permeability (absorption) potential.
\end{abstract}

Keywords: hydrazinyldiene-chroman-2,4-diones, physicochemical properties, doxorubicin, cytotoxicity, breast cancer cells

Accepted September 21, 2016

Published online September 28, 2016

Breast cancer is a heterogeneous disease involving different molecular subtypes, occurring and remaining within its original location and/or spreading outside the breast to other organs of the body such as the lungs, distant lymph nodes, skin, bones, liver or brain. Over one million of new breast cancer patients are diagnosed each year, accounting for

\footnotetext{
*Correspondence; e-mail: krml@ff.ukim.edu.mk; kmladenovska@yahoo.com
} 
L. Ballazhi et al:: Hydrazinyldiene-chroman-2,4-diones in inducing growth arrest and apoptosis in breast cancer cells: Synergism with doxorubicin and correlation with physicochemical properties, Acta Pharm. 67 (2017) 35-52.

$16 \%$ of all female cancers, $23 \%$ of invasive cancers in women and $18 \%$ of all cancer deaths worldwide for both males and females (1). Depending on the pathology and biology of the disease and patient characteristics, different strategies are applied to manage the disease and control the mortality, including surgery and radiation therapy as well as systemic endocrine, cytotoxic and biological/targeted therapies, employed in various combinations and sequences. However, severe toxic side effects and resistance to available therapies occur and are a strong motivation to the researchers to design and develop novel medicines and explore novel therapeutic combinations.

For many decades, anthracycline doxorubicin (Doxo) has been proven to be effective for early, locally advanced and inflammatory breast cancer as well as metastatic and recurrent one, killing cancer cells by intercalation into DNA and disruption of topoisomerase-II-mediated DNA repair and by generation of free radicals that damage cellular membranes, DNA and proteins. However, because of the fear of long-term cardiotoxicity, this drug is included in adjuvant regimens. In addition, resistance to Doxo, occurring as a multifactorial phenomenon, causes an incomplete response requiring combination chemotherapy (2).

Search for new agents against breast cancer that could also improve the therapeutic index of available anticancer medicines led us to coumarin coupled with isoxazole and thiazole moieties (3). Coumarin skeleton has been selected due to the antioxidant properties of coumarins and their effects on immune responses, cell growth and differentiation, specifically in breast cancer $(4,5)$. Structure-activity studies pointed to three functional groups in the coumarin core as essential for the inhibition of aromatase, 3-(4-chlorophenyl), 4-benzyl and 7-methoxy (4), while tricyclic coumarin-based sulfamates have been singled out as alternative inhibitors of steroid sulfatase, (5). In addition, 3,4-disubstituted coumarin derivatives have been proposed as selective estrogen receptor modulators (6), with 3-substituted coumarins further used for coupling with cytotoxic agents and bioconjugation with estradiol to improve selectivity (7). Thiazoles and isoxazoles are already proven precursors in the synthesis of medicinal compounds and heterocycles derived from them are widely evaluated in respect to their antiproliferative and tumor vasculardisrupting activities. It has been recently shown that thiazole antibiotics could suppress tumor growth in a human breast cancer xenograft, and repression of FoxM1 expression and proteasome inhibition was proposed as a mechanism of activity (8). Certain isoxazole derivatives were characterized as inhibitors of ATP $\mathrm{p}^{38 \alpha}$ mitogen activated protein kinase (MAPK), casein kinase 18, STAT3 phosphorylation and inhibitors of other targets for chemotherapy (9). In this respect, isoxazole analogue of curcumin has shown significant antitumor activity in the MCF-7 breast cancer cell line and its multidrug-resistant variant MCF-7R, being more potent (approximately twofold) compared to curcumin alone (10).

Considering all the above-mentioned information, compounds that combine coumarin core and isoxazoles or thiazoles in hydrazinyldiene-chroman-2,4-diones have been synthesized and structurally characterized in our previous studies (Table I) $(3,11,12)$. Three compounds having thiazole moiety, 3-[2-(1,3-thiazol-2-yl)hydrazinylidene]chroman2,4-dione (1c), 3-[2-(4-methyl-1,3-thiazol-2-yl)hydrazinylidene]chroman-2,4-dione (1d) and 3-[2-(4,5-dimethyl-1,3-thiazol-2-yl)hydrazinylidene]chroman-2,4-dione (1e), have been shown to exert more potent antiproliferative activity than the other synthesized compounds, inducing apoptosis in breast cancer cells MCF-7 and MDA-MB-231 (3) and in bone and lung metastatic cell lines from breast cancer SCP1833 and SCP4175 (11). In this study, the synergistic effects of these three hydrazinyldiene-chroman-2,4-diones and Doxo on 
L. Ballazhi et al.: Hydrazinyldiene-chroman-2,4-diones in inducing growth arrest and apoptosis in breast cancer cells: Synergism with doxorubicin and correlation with physicochemical properties, Acta Pharm. 67 (2017) 35-52.

Table I. Structure of synthesized hydrazinyldiene-chroman-2,4-diones (refs. 3, 12, 13)

\begin{tabular}{|c|c|c|c|c|c|c|}
\hline \multirow{9}{*}{$\mathrm{R}_{\backslash}^{3}$} & Compound & $x$ & $\mathrm{Y}$ & $\mathrm{R}^{1}$ & $\mathrm{R}^{2}$ & $\mathrm{R}^{3}$ \\
\hline & $1 \mathrm{a}$ & $\mathrm{N}$ & $\mathrm{N}$ & $\mathrm{H}$ & $\mathrm{H}$ & $\mathrm{H}$ \\
\hline & $1 b$ & $\mathrm{O}$ & $C$ & & $\mathrm{CH}_{3}$ & $\mathrm{H}$ \\
\hline & 1c & $\mathrm{C}$ & $S$ & $\mathrm{H}$ & $\mathrm{H}$ & \\
\hline & $1 d$ & $\mathrm{C}$ & $\mathrm{S}$ & $\mathrm{H}$ & $\mathrm{CH}_{3}$ & \\
\hline & $1 e$ & C & $\mathrm{S}$ & $\mathrm{CH}_{3}$ & $\mathrm{CH}_{3}$ & \\
\hline & $1 \mathrm{f}$ & $\mathrm{O}$ & $\mathrm{C}$ & & terc-butyl & $\mathrm{H}$ \\
\hline & $1 \mathrm{~g}$ & C & $S$ & $\mathrm{H}$ & $\mathrm{Br}$ & \\
\hline & $1 \mathrm{~h}$ & $\mathrm{O}$ & $\mathrm{C}$ & & $\mathrm{H}$ & $\mathrm{H}$ \\
\hline
\end{tabular}

cell proliferation and apoptosis, cell cycle distribution and migration capacity of breast cancer cell lines MCF-7 were evaluated. In addition, their physicochemical properties were determined and correlated with their structure and $I C_{50}$ values.

\section{EXPERIMENTAL}

\section{Cell culturing}

Human breast cancer MCF-7 cells were obtained from the American Type Culture Collection (ATCC, Manassas, USA) and were maintained in Dulbecco's modified Eagle's medium (DMEM, Invitrogen, Switzerland) containing $10 \%$ fetal bovine serum (FBS, Invitrogen), supplemented with glutamine $(0.03 \%, \mathrm{~m} / \mathrm{V})$ and $100 \mu \mathrm{g} \mathrm{mL} \mathrm{m}^{-1}$ benzyl penicillin, 100 $\mathrm{U} \mathrm{mL}^{-1}$ streptomycin and $2.5 \mu \mathrm{g} \mathrm{mL} \mathrm{m}^{-1}$ amphotericin (all obtained from Invitrogen). Cells were allowed to grow in tissue culture flasks (Corning, USA) and were kept in a $\mathrm{CO}_{2}$ incubator at $37{ }^{\circ} \mathrm{C}$ in a humidified atmosphere with $5 \% \mathrm{CO}_{2}$ and $95 \%$ air. For experimental purposes, cells from exponentially growing cultures were used.

\section{Cell viability assays}

For viability assays, 4-hydroxycoumarin (4-HC) (Merck, Germany), synthesized compounds (Table I; 1c, 1d, 1e) and Doxo (Sigma-Aldrich, USA) were dissolved in dimethyl sulfoxide (DMSO, Sigma-Aldrich) to get $10 \mathrm{mmol} \mathrm{L}^{-1}$ stock solutions and were stored at $-20{ }^{\circ} \mathrm{C}$. Further dilutions were made in complete DMEM containing $10 \%$ FBS. Cytotoxic effects of coumarin derivatives and 4-HC alone and in synergy with Doxo on MCF-7 cells were determined in 96-microwell plates by MTT [3-(4,5-dimethylthiazol-2-yl)-2,5-diphenyltetrazolium bromide] and alamarBlue assay as previously described $(3,11,13)$.

In the MTT assay, $100 \mu \mathrm{L}$ of growth medium (DMEM) was poured into each well of a 96-well plate plated with $5 \times 10^{3}$ MCF-7 cells per well. Cells were allowed to attach overnight and were then treated with the solutions of reference and synthesized compounds in increasing concentrations $\left(0.01,0.02,0.05,0.1 \mathrm{mmol} \mathrm{L}^{-1}\right)$, alone and in the presence of 
Doxo $\left(1 \mu \mathrm{mol} \mathrm{L}^{-1}\right)$. After 48 -h incubation at $37^{\circ} \mathrm{C}, 5 \% \mathrm{CO}_{2}$ and relative humidity $95 \%, 20$ $\mu \mathrm{L}\left(5 \mathrm{mg} \mathrm{mL}^{-1}\right)$ of the MTT reagent was added to each well and incubated for additional 4 $\mathrm{h}$ at $37^{\circ} \mathrm{C}$. After that, $100 \mu \mathrm{L}$ of solvent, consisting of $4 \mathrm{mmol} \mathrm{L}{ }^{-1} \mathrm{HCl}$ (Sigma-Aldrich) and $0.1 \%$ octylphenoxypolyethoxy ethanol (Nonidet P-40, AppliChem, Germany) in isopropanol (Sigma-Aldrich) was added to each well to solubilize the MTT crystals. The plates were covered with a foil and cells were agitated on an orbital shaker for $15 \mathrm{~min}$. Absorbance was then read at $590 \mathrm{~nm}$ in a microplate reader (SpectraMax M2 fluorometer, BucherBiotec Inc., USA). All experiments were performed at least three times, with four wells for each concentration of the agents tested. Control cells (C) were grown under the same conditions without addition of test compounds. In the alamarBlue assay, after the same period and incubation conditions, $10 \mu \mathrm{L}$ of alamarBlue reagent (10\% alamarBlue, Invitrogen) were added to each well and incubated for further $4 \mathrm{~h}$ at $37^{\circ} \mathrm{C}$. The plates were exposed to an excitation wavelength of $530 \mathrm{~nm}$ and the emission at $590 \mathrm{~nm}$ was read with a microplate reader. The percentage of viability was expressed as fluorescence counts in the presence of the tested compounds as a percentage of that in the vehicle control.

\section{Western blot analysis}

MCF-7 cell lines were treated for $48 \mathrm{~h}$ with either vehicle (0.05\% DMSO) or the indicated concentration of the reference (Doxo, $1 \mu \mathrm{mol} \mathrm{L}^{-1}$ ) and synthesized compounds $(20,50$ and $\left.100 \mu \mathrm{mol} \mathrm{L}^{-1}\right)$. Treated cells were homogenized in a lysis buffer $\left[25 \mathrm{mmol} \mathrm{L}{ }^{-1} \mathrm{Tris}-\mathrm{HCl}\right.$, pH 7.5, 150 mmol L-1 NaCl, 1 \% NP-40, $1 \mathrm{mmol} \mathrm{L}^{-1}$ EDTA, pH 8.0, 1 mmol L-1 PMSF (phenylmethylsulfonyl fluoride), $1 \mathrm{mmol} \mathrm{L} \mathrm{Na}_{3} \mathrm{VO}_{4}$ and $1 \times$ protease inhibitor cocktail-P2714, Sigma-Aldrich], centrifuged for $10 \mathrm{~min}$ at $14000 \times g$ and the supernatant was taken for protein determination. Equal amounts of protein $(30 \mu \mathrm{g})$ were separated on SDS-PAGE and transferred to nitrocellulose membranes. Western blot analysis was performed as previously described $(3,13)$ using antibodies against PARP [poly (ADP-ribose) polymerase], phospho-Thr ${ }^{308}$ Akt and the house-keeping protein GAPDH (glyceraldehyde-3-phosphate dehydrogenase). Secondary antibodies coupled to horseradish peroxidase were from GE Healthcare Life Sciences (Sweden). Signals were detected by enhanced chemiluminescence (ECL Western blotting substrate, Thermo Fisher Scientific, USA) on photosensitive film (ECL Hyperfilm, GE Healthcare Life Sciences).

\section{Flow cytometric analysis}

Cell cycle distribution was assayed by flow cytometry after DNA staining with propidium iodide (PI, Sigma-Aldrich). MCF-7 treated cells were trypsinized with trypsin-EDTA solution 1x (0.05\% trypsin, $0.02 \%$ EDTA, Sigma-Aldrich) and washed with a proteincontaining phosphate buffered saline (PBS 10× concentrate diluted to $1 \times$ concentration +5 $\%$ fetal bovine serum, Sigma-Aldrich) and centrifuged at 1100 $\times g$ for $10 \mathrm{~min}$. Cell pellets were re-suspended in $500 \mu \mathrm{L}$ PBS containing $5 \%$ FBS and centrifuged at $2000 \times g$ for 7 min at $4{ }^{\circ} \mathrm{C}$, then fixed in $70 \%$ ethanol and stored overnight at $-20{ }^{\circ} \mathrm{C}$. Fixed cells were washed with PBS, incubated with $25 \mu \mathrm{g} \mathrm{mL} \mathrm{L}^{-1}$ RNase (Merck) at $37^{\circ} \mathrm{C}$ for $30 \mathrm{~min}$ and then stained with $50 \mu \mathrm{g} \mathrm{mL}^{-1} \mathrm{PI}$. The samples were then incubated at $4^{\circ} \mathrm{C}$ in dark for $1 \mathrm{~h}$ and flow cytometric analyses were performed using a BD FACSCalibur ${ }^{\mathrm{TM}}$ (BD Biosciences, USA) instrument. The fraction of the total cell population present in the phases: $S$ (phase of DNA synthesis), $G_{1}$ (gap between the mitosis that gives rise to the cell and $S$ phase) and the 
phase of transition from $\mathrm{G}_{2}$ (gap between the $\mathrm{S}$ phase and mitosis that gives rise to two daughter cells) to $M$ (the phase of mitosis) $\left(\mathrm{G}_{2} / \mathrm{M}\right.$ phase) and the polyploidy peak was obtained from DNA histograms by mathematical modeling using Cell Quest software (v. 3.3; Becton Dickinson Biosciences, Switzerland). At least 20,000 cells were counted for each sample. Results from three independent experiments with three replicates per experiment were pooled.

\section{Scratch-wound migration assay}

MCF-7 cells were plated in 24-well-plates and when they grew into full confluence, a wound was induced onto monolayer cells by scraping a gap using a micro-pipette tip (100 $\mu \mathrm{L})$. Then, the compounds in different concentrations $\left(0.01,0.02,0.05,0.1 \mathrm{mmol} \mathrm{L}^{-1}\right)$, alone or with Doxo $(1 \mu \mathrm{mol} \mathrm{L}-1)$, were immediately added and maintained for $24 \mathrm{~h}$. The speed of wound closure of treated and untreated cells was compared. Photographs were taken under 10× magnification using phase-contrast microscopy (Zeiss Microscopy, Germany) immediately after wound incision and at later time points. The gap distance was quantitatively evaluated using ImageJ software (v. 1.48; Wayne Rasband, NIH, USA) measuring the scratch area at $0 \mathrm{~h}$ and $24 \mathrm{~h}$ after incubation. Data are expressed as area reduction from time points 0 to $24 \mathrm{~h}$. The results were pooled from three independent experiments with three replicates per experiment.

\section{Determination of physicochemical properties}

Solubility of the reference compound and synthesized compounds was determined in water and in a phosphate buffer solution (PBS, $\mathrm{NaH}_{2} \mathrm{PO}_{4}, 0.25 \mathrm{~mol} \mathrm{~L}-1, \mathrm{pH}$ 7.4) using a static equilibrium method. An excess of the compound was exposed to the solvent, the mixtures were allowed to be stirred in a thermostatic water bath at $37 \pm 1{ }^{\circ} \mathrm{C}$ (SWB 20, Haake, USA) and the samples were collected and assayed once, every 5 hours, and replicated three consecutive times. Afterwards, the supernatant solutions previously obtained by ultracentrifugation at 12,000 rpm for $15 \mathrm{~min}$ were filtered to ensure that they were free of particulate matter before sampling. Concentration was determined by UV/VIS absorption at $\lambda_{\max } 285 \mathrm{~nm}$ for $4-\mathrm{HC}, 405 \mathrm{~nm}$ for $\mathbf{1 b}, 410 \mathrm{~nm}$ for $1 \mathrm{c}$ and $420 \mathrm{~nm}$ for $\mathbf{1 d}$ (Shimadzu UV - 1800, Japan), after appropriate dilution and interpolation from previously constructed calibration curves for each compound. All the solubility experiments were repeated at least three times and the mean values were regarded as the measured results.

Distribution coefficients $\left(\log D_{7.4 \mathrm{exp}}\right)$ between $n$-octanol and PBS $\left(\mathrm{NaH}_{2} \mathrm{PO}_{4}, 0.25 \mathrm{~mol} \mathrm{~L}^{-1}\right.$, $\mathrm{pH}$ 7.4) were determined by the shake-flask method. The reference and synthesized compounds were dissolved in equal volumes of DMSO and EtOH (p.a. $96 \%$ ethanol, Alkaloid, Macedonia) at a concentration of approx. $1 \mathrm{mg} \mathrm{mL}^{-1}$ to obtain the stock solution. The amounts of samples were chosen so that absorption of 0.2 to 0.8 in the water phase was reached after partitioning. The experiments were performed in the system $n$-octanol/PBS $(1: 2, V / V)$. An adequate volume of the stock solution was added to a mixture of the organic and aqueous phases (mutually saturated by previous shaking for $24 \mathrm{~h}$ at the temperature of the experiment) and placed into a glass vial. The phases were shaken together on the same mechanical shaker for $2 \mathrm{~h}$ at $25 \pm 0.1^{\circ} \mathrm{C}$. Equilibration was generally reached within half an hour. After equilibration, the mixture was centrifuged for $10 \mathrm{~min}$ at $5000 \mathrm{rpm}$, the octanol phase was removed and the concentration of the compound was assayed in both 
phases spectrophotometrically at $\lambda_{\max } 290 \mathrm{~nm}$ for $4-\mathrm{HC}, 405 \mathrm{~nm}$ for $1 \mathrm{c}, 410 \mathrm{~nm}$ for $\mathbf{1 d}$ and $420 \mathrm{~nm}$ for 1e. Distribution coefficients were calculated as the ratio between the molar concentration in $n$-octanol and the aqueous phase. All experiments were done in triplicate.

For determination of $\mathrm{pK}_{\mathrm{a}}$ values, $\mathrm{pH}$ metric titration and the UV/Vis spectrophotometric method were applied. For the $\mathrm{pH}$ metric method, the compounds were dissolved separately in acetonitrile $\left(10^{-3} \mathrm{~mol} \mathrm{~L}^{-1}\right)$ and then the solutions were diluted 1:100 with PBS (pH 7.4, $10 \mathrm{mmol} \mathrm{L}^{-1}, 8.0 \mathrm{~g} \mathrm{NaCl}, 1.16 \mathrm{~g} \mathrm{~K}_{2} \mathrm{HPO}_{4}, 0.2 \mathrm{~g} \mathrm{KH}_{2} \mathrm{PO}_{4}$ and $0.2 \mathrm{~g} \mathrm{KCl}$ in up to $1 \mathrm{~L}$ deionized water) and mixed with a magnetic stirrer during titration. Titration was carried out in triplicate at ambient temperature of $23 \pm 1^{\circ} \mathrm{C}$ to ensure reproducibility using a $\mathrm{pH}$ meter (Sartorius PB-20, Sartorius AG, Germany) with declared accuracy of \pm 0.01 and temperature corrections. $\mathrm{p} K_{\mathrm{a}}$ values were estimated from the graph constructed from the dependence of $\mathrm{dpH} / \mathrm{d} V$ vs. $\mathrm{HCl}$ volume. For the second method, the UV/Vis spectra of the investigated compounds $\left(\sim 10^{-5} \mathrm{~mol} \mathrm{~L}^{-1}\right)$ and an appropriate blank were recorded in a $\mathrm{pH}$ range 1 to 7 , with 0.5 increments. The UV/Vis spectra were recorded, immediately after preparing the solutions, on a Varian Cary 50 Spectrophotometer (Varian Inc., USA) in 1-cm quartz cells, in the range from 190 to $650 \mathrm{~nm}$, with resolution of $0.5 \mathrm{~nm}$ and scan rate of $300 \mathrm{~nm}$ $\mathrm{min}^{-1}$ at room temperature.

Experimental values of water solubility were compared with the calculated ones, obtained with ALOGPS 2.1 software (VCCLAB, Virtual Computational Chemistry Laboratory ,, Germany; http://www.vcclab.org; last access date January 15, 2016), while those of the other physicochemical parameters with ChemAxon's software (ChemAxon, Hungary, www.chemaxon.com/products/calculator-plugins/property-predictors; last access date January 15, 2016).

\section{Data presentation and statistical analysis}

Cell survival was calculated relative to the controls. The $50 \%$ inhibitory concentration $\left(I C_{50}\right)$ was determined as the anticancer drug concentration causing $50 \%$ reduction in cell viability and was calculated from the viability curves by linear interpolation between the values immediately above and below the $50 \%$ inhibition using the Bliss software (Bliss Co, Castro Valley, CA, USA). The results were presented as mean \pm SD and the statistical analysis was performed using the one-way analysis of variance (ANOVA) followed by Bonferroni's post hoc test for multiple comparisons (GraphPadInStat version 3.00 for Windows NT, GraphPad Software, San Diego, CA, USA).

\section{RESULTS AND DISCUSSION}

Cytotoxic and antiproliferative effects of synthesized hydrazinyldiene-chroman-2,4-diones and doxorubicin

Effects of the coumarin derivatives 4-HC and Doxo on MCF-7 cell viability, alone or in combination, evaluated by MTT and alamarBlue assays, are presented in Figs. 1a and b, respectively. No significant difference in antiproliferative effect of Doxo on the MCF-7 cells was observed when the two assays were compared, with cell viability being preserved approx. $61 \%$ when Doxo $\left(1 \mu \mathrm{mol} \mathrm{L}^{-1}\right)$ was administered. However, similarly to a previous study, in which synergy between coumarin derivatives and tamoxifen in blocking the 
growth of MCF-cells was evaluated (13), non-significant differences in cell viability were observed when the data from the MTT and alamarBlue assays were compared, with the percentages of viable cells being higher in the MTT assay. For example, 4-HC alone induced no apoptosis at concentration $\leq 20 \mu \mathrm{mol} \mathrm{L}^{-1}$ when the alamarBlue assay was applied, with cell viability slightly decreasing (approx. $7 \%$ ) when the concentration was increased to $100 \mu \mathrm{mol} \mathrm{L}^{-1}$ (Fig. 1b). However, when the MTT assay was applied, using the same concentration, the decrease in cell viability was more than $13 \%$ (Fig. 1a). Also, for the synthesized coumarin derivatives, higher cell viability was observed in the alamarBlue assay,
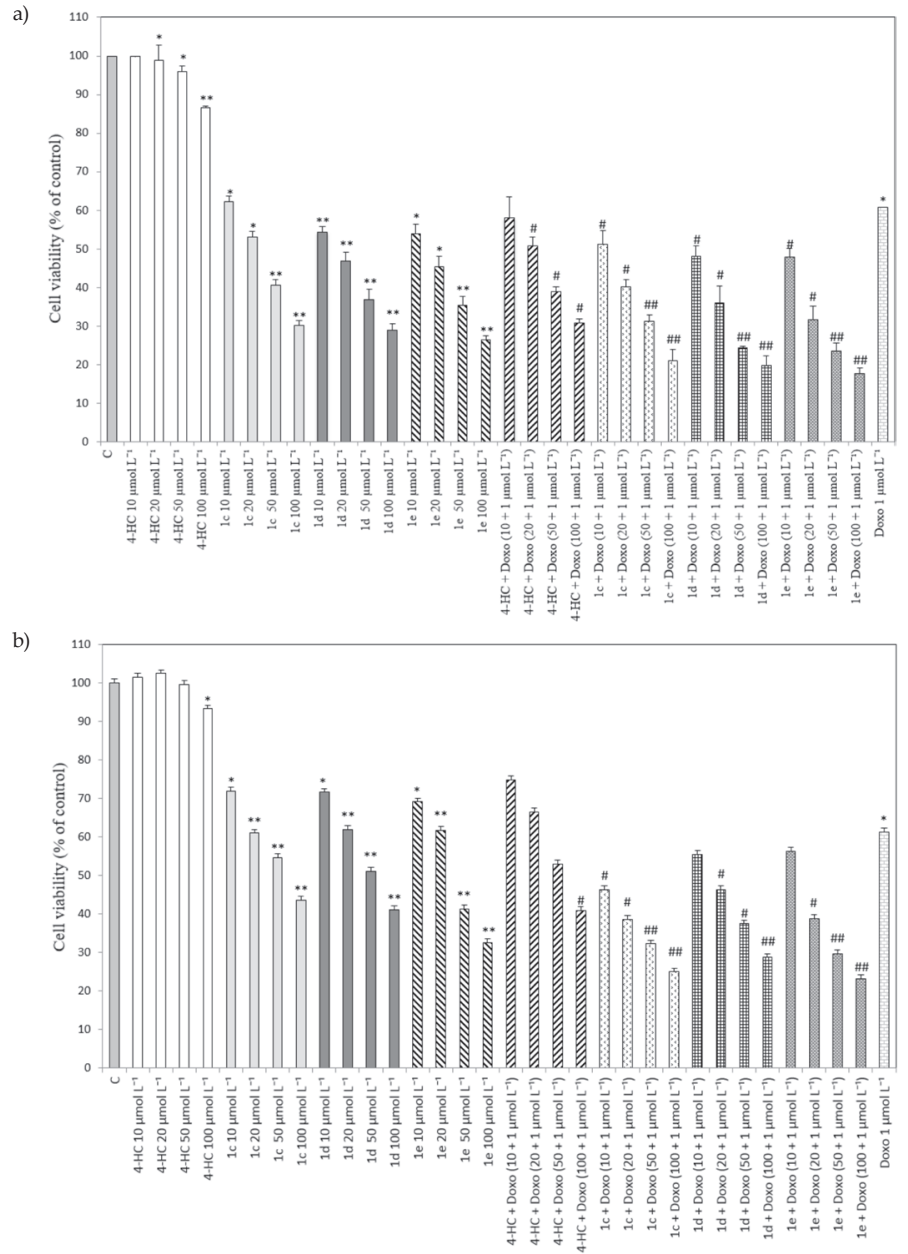

Fig. 1. Effects of Doxo, 4-HC and synthesized hydrazinyldiene-chroman-2,4-diones, alone and in combination, on viability of MCF-7 breast cancer cells, measured by: a) MTT and b) alamarBlue assay. Percentage of viable cells was determined as a ratio of treated cells to controls (C). Results are expressed as mean \pm SD of triplicate experiments. Statistically significant difference when compared to the control: ${ }^{*} p<0.05,{ }^{* *} p<0.01$; to Doxo-treated cells: ${ }^{*} p<0.05,{ }^{* \#} p<0.01$. 
L. Ballazhi et al.: Hydrazinyldiene-chroman-2,4-diones in inducing growth arrest and apoptosis in breast cancer cells: Synergism with doxorubicin and correlation with physicochemical properties, Acta Pharm. 67 (2017) 35-52.

Table II. Cytotoxicity of 4-HC and its synthesized derivatives against MCF-7 breast cancer cell lines determined by MTT and alamarBlue assays

\begin{tabular}{ccccc}
\hline & \multicolumn{2}{c}{$\begin{array}{c}\text { MTT assay } \\
I C_{50}\left(\mu \mathrm{mol} \mathrm{L}^{-1}\right)^{\mathrm{a}}\end{array}$} & \multicolumn{2}{c}{$\begin{array}{c}\text { AlamarBlue assay } \\
I C_{50}\left(\mu \mathrm{mol} \mathrm{L}^{-1}\right)^{\mathrm{a}}\end{array}$} \\
\cline { 2 - 5 } Compound & $\begin{array}{c}\text { Compound } \\
\text { alone }\end{array}$ & $\begin{array}{c}\text { Compound+Doxo } \\
\left.(1 \mu \mathrm{mol} \mathrm{L})^{-1}\right)\end{array}$ & $\begin{array}{c}\text { Compound } \\
\text { alone }\end{array}$ & $\begin{array}{c}\text { Compound+Doxo } \\
\left.(1 \mu \mathrm{mol} \mathrm{L})^{-1}\right)\end{array}$ \\
\hline 4-HC & $>100$ & $49.668 \pm 0.548^{\mathrm{b}}$ & $>100$ & $49.838 \pm 0.559^{\mathrm{b}}$ \\
1c & $49.784 \pm 0.689$ & $20.107 \pm 0.768^{\mathrm{b}}$ & $49.966 \pm 1.167$ & $20.117 \pm 1.074^{\mathrm{b}}$ \\
1d & $49.763 \pm 0.873$ & $20.067 \pm 1.658^{\mathrm{b}}$ & $49.802 \pm 0.778$ & $20.162 \pm 0.902^{\mathrm{b}}$ \\
1e & $49.798 \pm 0.864$ & $19.839 \pm 0.581^{\mathrm{b}}$ & $49.562 \pm 0.707$ & $19.851 \pm 0.519^{\mathrm{b}}$ \\
\hline
\end{tabular}

${ }^{a}$ Mean \pm SD from at least three independent experiments.

b Statistically significant difference in $I C_{50}$ between the compounds applied alone and in synergy with Doxo at $p<0.0001$.

ranging from 69 to $72 \%$ for the lowest $\left(10 \mu \mathrm{mol} \mathrm{L}^{-1}\right)$ and from 32 to $44 \%$ for the highest concentration $\left(100 \mu \mathrm{mol} \mathrm{L}^{-1}\right)$ used (Fig. $\left.1 \mathrm{~b}\right)$ vs. 54 to $62 \%$ and 26 to $30 \%$, respectively, obtained with the MTT assay (Fig. 1a). In addition, the MTT assay was used (31-56 vs. 41-74 $\%$ with alamarBlue assay) as well as the combination treatment of Doxo $\left(1 \mu \mathrm{mol} \mathrm{L}^{-1}\right)$ and any of the synthesized coumarin derivatives separately (Figs. 1a and b). With the increase in the concentration of the coumarin derivative, when it was concomitantly administered with Doxo, the effect increased significantly in comparison with the control values, being $49 \%$ viable cells for the lowest $\left(10 \mu \mathrm{mol} \mathrm{L}^{-1}\right)$ and $20 \%$ for the highest concentration (100 $\mu \mathrm{mol} \mathrm{L}{ }^{-1}$ ) in the MTT assay (Fig. 1a) vs. 53 and $26 \%$ for the lowest and highest concentration in the alamarBlue assay (Fig. 1b), respectively. As shown in Fig. 1a, combination treatment of $1 \mu \mathrm{mol} \mathrm{L}-1$ Doxo and $20 \mu \mathrm{mol} \mathrm{L}^{-1} 4$-HC in MTT and 10-50 $\mu \mathrm{mol} \mathrm{L}^{-1} 4$-HC in the alamarBlue assay showed no decrease in cell viability in comparison with Doxo alone. On the contrary, the synergy effect of Doxo and coumarin derivatives resulted in a significant cell viability decrease by $16-21 \%$ for the lowest $\left(10 \mu \mathrm{mol} \mathrm{L}^{-1}\right)$ and by $65-71 \%$ for the highest $\left(100 \mu \mathrm{mol} \mathrm{L}^{-1}\right)$ coumarin derivative concentration in MTT, and 8-24 and 53-62 \% in the alamarBlue assay, resp., when compared to Doxo $\left(1 \mu \mathrm{mol} \mathrm{L}^{-1}\right)$ alone.

However, as shown in Table II, no significant difference in $I C_{50}$ of the synthesized compounds was observed when the values from both assays were compared. In addition, similar values for $I C_{50}$ were obtained for all synthesized compounds when they were administered alone (approx. $50 \mu \mathrm{mol} \mathrm{L}-1$ ) and in combination with Doxo (approx. $20 \mu \mathrm{mol} \mathrm{L}^{-1}$ ).

In synergy with Doxo, their $I C_{50}$ values decreased significantly $(p<0.0001)$, with the coumarin derivative 3-[2-(4,5-dimethyl-1,3-thiazol-2-yl)hydrazinylidene]chroman-2,4-dione (1e) being more potent than the other derivatives, but non significantly.

\section{AlamarBlue vs. MTT assay}

Non-significant differences in cell viability when the data from the two assays were compared can be partly explained by the different sensitivity of assay reagents to the effects of the compounds on cellular metabolism. Namely, the alamarBlue assay is based on 
L. Ballazhi et al:: Hydrazinyldiene-chroman-2,4-diones in inducing growth arrest and apoptosis in breast cancer cells: Synergism with doxorubicin and correlation with physicochemical properties, Acta Pharm. 67 (2017) 35-52.

the ability of viable and metabolically active cells to reduce the oxidized form of resazurin induced in cytosol by various mitochondrial enzymes, by accepting electrons not only from NADPH, FADH, FMNH, NADH but also from numerous cytochromes, unlike MTT which cannot be reduced to formazan by the cytochromes since its midpoint potential is intermediate between that of the electron donors and cytochromes (14). Another factor influencing the conversion of MTT to formazan is the number of mitochondria present in the cell, with larger cells having more mitochondria and thus showing a higher rate of tetrazolium conversion. In addition, defective mitochondria also retain the ability to reduce tetrazolium. Thus, all these factors together may lead to false estimation of the cell number, suggesting that resazurin is a better redox indicator for cell viability. Different cytotoxic effects emerging from assay performance may also explain the observed differences in cell viability. It is well-known that in the alamarBlue assay, the cells are unaffected by the indicator, remaining fully functional and viable, unlike the MTT assay where intracellular formazan crystals must be solubilized with DMSO or $\mathrm{HCl}$ /isopropanol for quantification, which destroys the investigated cells (14). Different cytotoxic effects were also observed by Hamid et al. (15), who evaluated the effects of a wide range of medicines in the human hepatoma cell line HepG2 using the two assays. Similarly, in our data, cytotoxicity of comparable $I C_{50}$ values was shown in both assays. Different levels of induction and/or inhibition of the metabolic enzymes responsible for transformation of cell toxicity end points by the tested compounds could be also a reason for obtaining different results from the two assays, as observed for dicumarol (15). In this respect, the fact that 4-HC acts as an inhibitor of microsomal mixed function oxidase (16) could explain why the combination treatment of Doxo and 4-HC did not decrease cell viability in comparison with Doxo alone when 4-HC in lower concentrations was administered. Namely, the Doxo bioactivation network is comprised of a system of reduction/oxidation reactions that lead to formation of toxic Doxo metabolites and reactive oxygen species (ROSs) responsible for lipid peroxidation and membrane damage, DNA damage, oxidative stress and trigger apoptotic pathways of cell death (2). Reductive conversion of Doxo is characterized by the oneelectron reduction of the quinone moiety of Doxo, via NADPH and cytochrome P450 reductase, into a semiquinone radical. Once the semiquinone radical has been generated, it can exert direct toxic effects or be oxidized back to the quinone form. It has been reported that the ability of Doxo to undergo reductive conversion is dependent on the availability of molecular oxygen and NADPH, and the activities of several intracellular enzymes such as superoxide dismutase, glutathione peroxidase and NADPH oxidases. In addition, other enzymatic systems are also known to activate Doxo, e.g., xanthine oxidase (XO), DT-diophorase and nitric oxide synthase, to form ROSs. Literature data (17) indicate that certain representatives of coumarins are known to inhibit the enzyme $\mathrm{XO}$ and are capable of absorbing ROSs produced by XO and other enzymes.

\section{Induction of apoptosis with synthesized hydrazinyldiene-chroman-2,4-diones and doxorubicin}

As illustrated in Fig. 2, full PARP (116 kDa) was cleaved into $85 \mathrm{kDa}$ fragments at all concentrations of 1c, 1d and 1e alone and in combination with Doxo, which was not observed for the control and 4-HC alone. In addition, the levels of phospho-Thr ${ }^{308} \mathrm{Akt}$ were down-regulated by the treatment of MCF-7 cells with coumarin derivatives alone or in combination with Doxo, when compared to the control treated cells, which correlates with 
a)

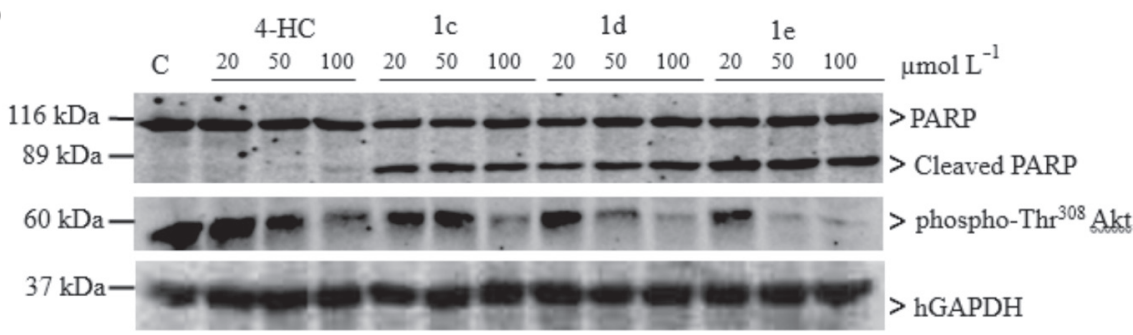

b)

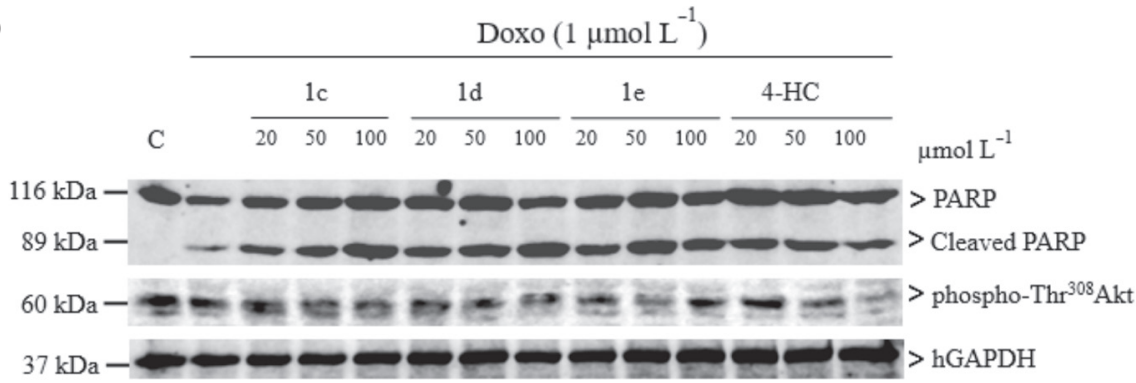

Fig. 2. Western blot analysis of cleaved PARP and phospho-Thr ${ }^{308}$ Akt after incubation of MCF-7 cells with the vehicle (C), 4-HC and synthesized hydrazinyldiene-chroman-2,4-diones: a) alone and b) in combination with Doxo for $48 \mathrm{~h}$. Western blot analysis was performed using antibodies against PARP (upper panels), phospho-Thr ${ }^{308} \mathrm{Akt}$ (middle panels) and the house-keeping protein GAPDH (lower panels).

reduced proliferation and increased apoptosis. The same was observed when the apoptotic effect of these compounds in synergy with tamoxifen was evaluated, where all concentrations of $\mathbf{1 c}, \mathbf{1} \mathbf{d}$ and $\mathbf{1 e}$ in synergy with tamoxifen led to reduced protein expression of $116 \mathrm{kDa}$ full length PARP and down-regulation of the protein kinase involved in cell growth and survival in comparison with the control and combination of tamoxifen and 4-HC treated cells (13). Similar results were obtained when analogues having coumarin and benzimidazole moieties were evaluated for their anticancer activity in different human cancer cell lines (17). Fluorescence-activated cell sorting and Western blotting analyses identified three compounds that induced caspase-dependent apoptosis. Expression of several cancer-related genes (DDIT4, PDGFRA, LRP8, IGFBP5) and Western blotting data on key signaling proteins indicated that the compound 7-(diethylamino)-3-(1-methyl- $1 \mathrm{H}$ benzimidazol-2-yl)-2H-chromen-2-one inhibited significantly the PI3K-AKT-mTOR pathway, an intracellular signaling pathway critical in cell proliferation and apoptosis.

\section{Effect of synthesized hydrazinyldiene-chroman-2,4-diones and doxorubicin on cell cycle arrest}

It is well known that cell cycle arresting compounds rely on different mechanisms of action. Some compounds interfere with the Cdk/cyclin complexes, leaving cells stuck at 
L. Ballazhi et al:: Hydrazinyldiene-chroman-2,4-diones in inducing growth arrest and apoptosis in breast cancer cells: Synergism with doxorubicin and correlation with physicochemical properties, Acta Pharm. 67 (2017) 35-52.

the $\mathrm{G}_{2} / \mathrm{M}$ phase border, while the others affect CaMK II phosphorylation, inducing arrest at the $G_{1}$ phase. Other mechanisms of action include interference with RNA function and inhibition of protein synthesis.

Effects of the synthesized coumarin derivatives,4-HC and Doxo on cell cycle arrest, alone or in combination, are illustrated in Figs. 3a and b. As shown in Fig. 3b, when MCF-7 cells were exposed to Doxo only $\left(1 \mu \mathrm{mol} \mathrm{L}^{-1}\right)$, higher percentage of cells were arrested in the sub- $\mathrm{G}_{1}$ and $\mathrm{G}_{2} / \mathrm{M}$ phases. The effect of Doxo on the MCF-7 cell cycle profile was previously assessed by Bar-On et al. (18), who found that Doxo arrested MCF-7 cells at $\mathrm{G}_{1} / \mathrm{S}$ and $\mathrm{G}_{2} / \mathrm{M}$ checkpoints, whereas the MDA-MB-231 cells were arrested at $\mathrm{G}_{2} / \mathrm{M}$ only. Doxo decreased the S-phase kinase-associated protein 2 (Skp2) mRNA and protein levels in MCF7 cells, but had the opposite effect in MDA-MB-231 cells. In addition, p27 levels were slightly decreased, whereas p53 and p21 levels were significantly upregulated in Doxo-treated MCF-7 cells. In contrast, p27 levels were unaffected by Doxo treatment in MDA-MB-231 cells, but cyclin B levels were markedly increased. Similarly, when the effect of Doxo on cell cycle progression and its correlation with DNA damage and cytotoxicity in p53-mutant P388 cells was studied, P388 cells synchronized in $S$ and $G_{2} / M$ phases were $>3$-fold more sensitive to Doxo than cells in the $G_{1}$ phase. These results suggest that anthracyclineinduced cytotoxicity is cell-cycle dependent and is mediated, at least in part, by disturbance of the regulation of the p34Cdc2/cyclin B1 complex, thus leading to $\mathrm{G}_{2} / \mathrm{M}$ phase arrest (18). However, when the effects of Doxo in Hct-116 human colon carcinoma cells were studied in order to find out if there was a time/concentration range for optimal Doxo-induced apoptosis, continuous $(24 \mathrm{~h})$ treatment with $5 \mu \mathrm{mol} \mathrm{L}{ }^{-1}$ Doxo resulted in cell cycle arrest in the $G_{0} / G_{1}$ phase, which was neither accompanied by phosphorylation and activation of p53 nor enhanced expression of p21 (19). In contrast, bolus (3 h) treatment resulted in a dose-dependent decrease of viable cells and concomitant increase of apoptosis and led to phosphorylation of p53 at serine 392, induction of p21, $\mathrm{G}_{2}$ arrest and increase of proapoptotic protein Bax. These results suggested that Doxo was able to induce cell death by apoptosis only under particular dose and treatment conditions and implied a completely different cellular response following bolus or continuous exposure to Doxo (19).

Our results indicate that after treatment with synthesized compounds alone, irrespective of the concentration used ( 20 or $50 \mu \mathrm{mol} \mathrm{L}^{-1}$ ), higher percentages of the MCF-7 cells were arrested in phases when they got ready to duplicate $\left(G_{1}: 68-75 \%\right)$ and/or get an opportunity to repair damage before mitosis (enhanced $\mathrm{G}_{2} / \mathrm{M}$ peak: $19-30 \%$ ) (Fig. 3a). When the combination of Doxo $(1 \mu \mathrm{mol} \mathrm{L}-1)$ and the compounds in concentration of $50 \mu \mathrm{mol} \mathrm{L}-1$ was applied, the number of cells in the $S$ phase decreased, which led to accumulation of cells in the $\mathrm{G}_{2} / \mathrm{M}$ phase. In parallel, more cells containing fragmented DNA were detected in the sub-G1 fraction (Fig. 3b). Thus, compared to the compounds alone, the percentage of cells in the $\mathrm{G}_{2} / \mathrm{M}$ phase increased by $14-38 \%$ and in the sub- $\mathrm{G}_{1}$ phase by $89-146 \%$ when the combination of Doxo and the compounds was applied (Fig. 3b). This confirmed the inhibition of cell growth by cell-cycle arrest in the $G_{2} / M$ phase. These results are partly different from the results obtained by Musa et al. (20), who evaluated the cytotoxic activity of two acetoxycoumarins against the different cancer cells. The compounds caused cell cycle arrest at different phases in the A549 lung and CRL 1548 liver cancer cell lines $\left(S, G_{2}\right.$, $\mathrm{G}_{1}$ ), indicating a different mode of cell death or target action for different coumarin derivatives. However, the cytotoxic effects of the synthesized compounds observed in our study are in agreement with earlier findings that coumarin and its derivatives inhibit cell growth by inducing cell cycle arrest in the $G_{1}$ phase, obtained by Goel et al. (22) for a lung 
a)

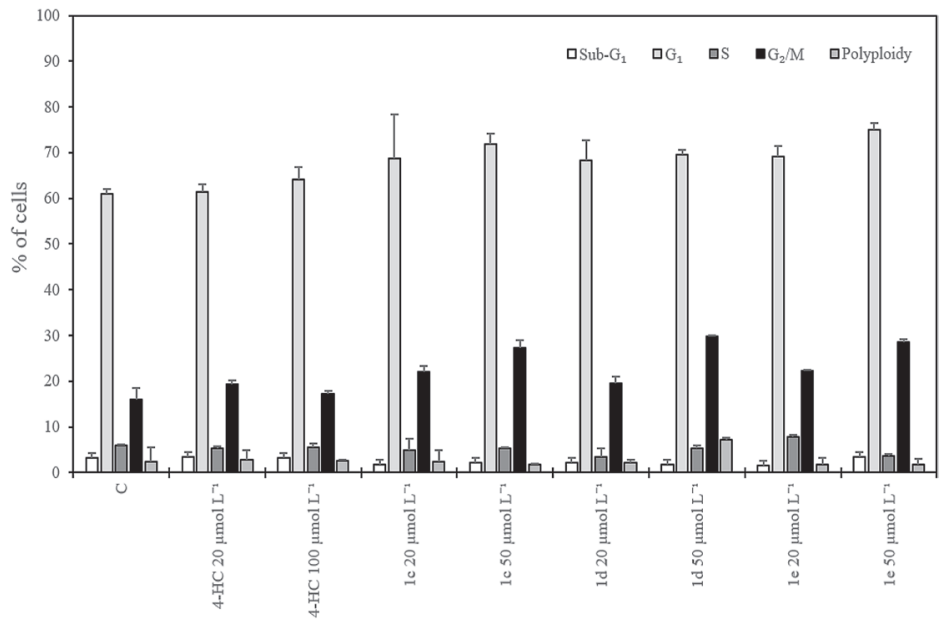

b)

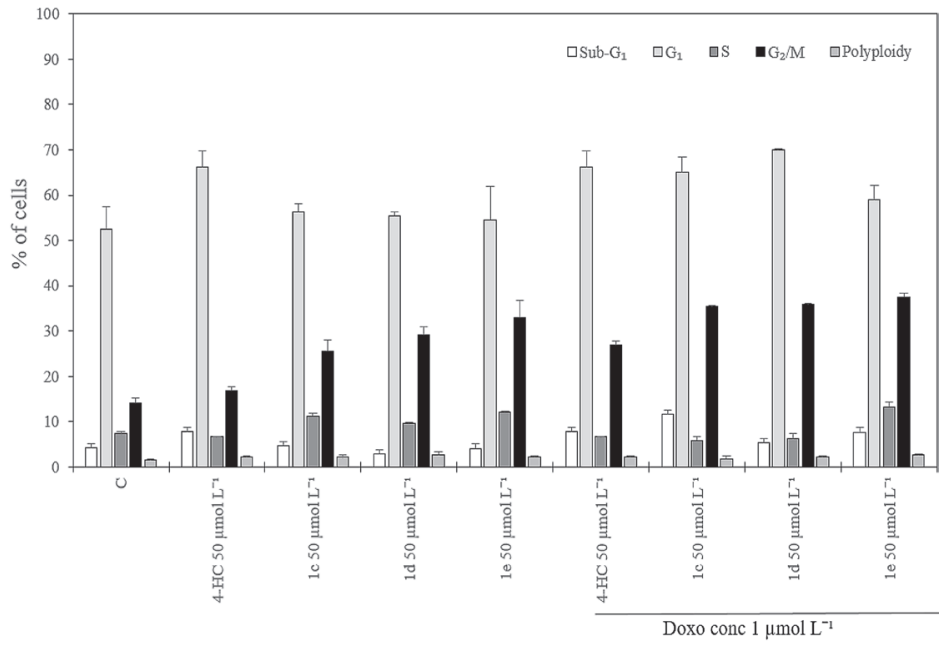

Fig. 3. Effects of the treatment on cell cycle progression. Cells treated $48 \mathrm{~h}$ with either: a) synthesized hydrazinyldiene-chroman-2,4-diones alone or b) in combination with Doxo. Results are expressed as mean \pm SD of triplicate experiments.

carcinoma cell line and by Alesiani et al. (23) for murine B16 and human A375 melanoma cell lines. In addition, in the study of Haghighi et al. (24), 7-isopentenyloxycoumarin arrested cells in the $G_{2} / M$ stage when its effect on cell cycle arrest in transitional cell carcinoma 5637 cells was studied.

Since it is known that upregulation of cyclin B1/Cdc2 kinase activity is involved in the $\mathrm{G}_{2} / \mathrm{M}$ stage transition of the cell cycle and, on the other hand, cells are arrested in the $M$ stage when microtubule network is disrupted, it is possible that the synthesized coumarin derivatives acted on the $G_{2}$ checkpoint or as microtubule inhibitors. This was confirmed in several studies $(24,25)$, which identified the ability of different coumarins to activate 
L. Ballazhi et al:: Hydrazinyldiene-chroman-2,4-diones in inducing growth arrest and apoptosis in breast cancer cells: Synergism with doxorubicin and correlation with physicochemical properties, Acta Pharm. 67 (2017) 35-52.

caspase-3, induce internucleosomal DNA laddering fragmentation, and gradually decrease the expression of $\mathrm{G}_{0} / \mathrm{G}_{1}$-associated proteins and the anti-apoptotic proteins Bcl-2 and $\mathrm{Bcl}-\mathrm{xL}$, while increasing the expression of the pro-apoptotic protein Bax.

\section{Effects of synthesized hydrazinyldiene-chroman-2,4-diones and doxorubicin on cell migration}

For cancer development and metastasis, the potential of cells to migrate or to grow invasively occurs in addition to proliferation, the most important disease-causing factor. Therefore, to assess if coumarin derivatives had any effect on migration ability of the MCF7 cells, a wound closure assay was applied and the results are presented in Figs. $4 \mathrm{a}$ and $\mathrm{b}$. Similarly sized wounds were introduced into monolayer MCF-7 cells at $0 \mathrm{~h}$. In control cells, the gap of the wound was filled gradually by migrating cells and $16 \mathrm{~h}$ after wound induction, the gap was almost closed. In contrast, after exposure to synthesized coumarin derivatives, the speed of wound closure was much lower and the wound was still widely open at $16 \mathrm{~h}$ post exposure (Fig. 4a). On average, wound coverage in the MCF-7 cells was $45 \%$ after treatment with coumarin derivatives and this percentage significantly decreased to $23 \%$ when the compounds were administered in synergy with Doxo (49\% decrease) (Fig. 4b). No significant difference between the compounds in suppression of cell migration was observed in either case. These results are significantly different from the ones obtained with Doxo alone (59 \%), and 4-HC alone (73\%) and in synergy with Doxo (42 \%) (Fig. 4b). One can say that the decreased number of migrating cells was a consequence of reduced proliferation, since a significant difference was detected between the controls and the treated cells in MTT and alamarBlue assays when they were exposed to the same concentration of coumarin derivatives $\left(10 \mu \mathrm{mol} \mathrm{L}^{-1}\right)$ as that used in the migration assay (Figs. $1 \mathrm{a}$ and $\mathrm{b}$ ). Hence, it should be emphasized that the migration ability of the cells was not affected by the antiproliferative effect of the compounds since no significant difference in cell viability was detected between the treated cells and the controls in either MTT or alamarBlue assay after $16 \mathrm{~h}$, the period during which the effect of coumarin derivatives on MCF-7 migration was analyzed.
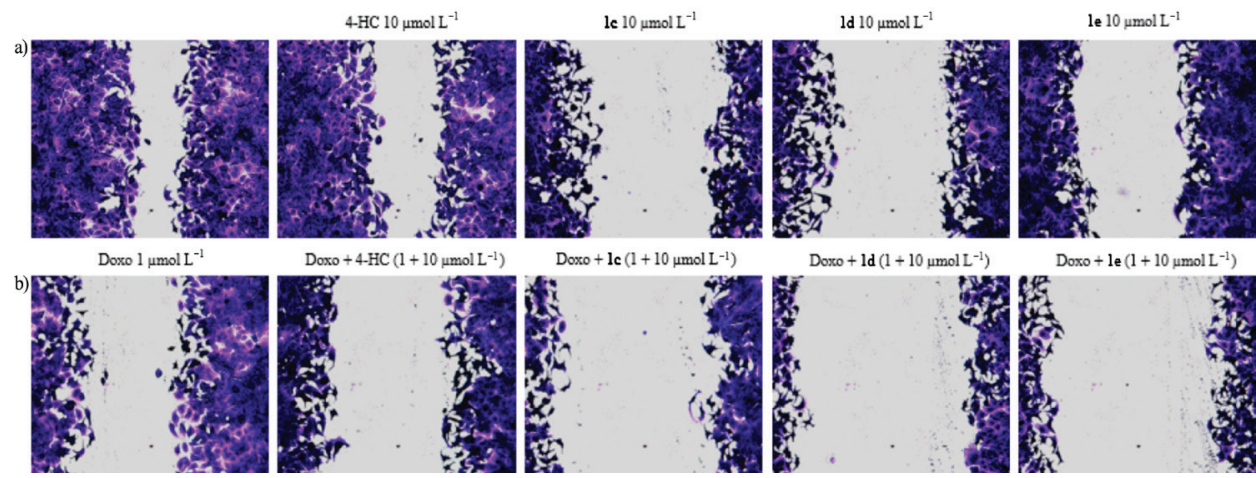

Fig. 4. Effect of 4-HC and synthesized hydrazinyldiene-chroman-2,4-diones alone and in synergy with Doxo on MCF-7 cell migration. a) Photographs of migrating cells, b) summary of wound assay results (mean $\pm \mathrm{SD}$ of triplicate experiments). Statistically significant difference when compared to the control (C): ${ }^{*} p<0.05,{ }^{* *} p<0.01$; to Doxo-treated cells: ${ }^{*} p<0.05,{ }^{* *} p<0.01$. 
As the speed of wound closure reflects the migration ability of breast cancer cells, these results indicate that treatment with coumarin derivatives can inhibit cell migration. Furthermore, combination treatment of the MCF-7 cells demonstrated additive inhibition of migration, suggesting that adding coumarin derivatives to a Doxo therapy may further reduce the risk of metastasis. Similar results were obtained when certain 7-substituted coumarins (umbelliferone, scoparone and herniarin) were analyzed for tumor cell motility suppression by a wound assay model, where all compounds reduced migration of laryngeal cancer cells in a dose-dependent manner (26). In addition, osthole, a natural coumarin derivative (7-methoxy-8-isopentenoxycoumarin), was shown to be effective in inhibiting the migration and invasion of breast cancer cells (MCF-7 and MDA-MB 231) in a wound healing assay (27). It was proposed that inhibition of matrix metalloproteinase-2 and enzyme activity might be one of the causes that led to the inhibition of migration and invasion.

\section{Physicochemical properties of synthesized hydrazinyldiene-chroman-2,4-diones}

Physicochemical properties of the synthesized compounds were correlated with their structure and cytotoxic activity. Melting points of the synthesized compounds had been previously determined and presented and they ranged from approx. 207 (1e) to $219{ }^{\circ} \mathrm{C}(\mathbf{1 d})$ $(3,12)$. In all the three compounds $(\mathbf{1} \mathbf{c}, \mathbf{1 d}, \mathbf{1 e})$, there are 5 centers of hydrogen bonds; four hydrogen bond acceptors ( $\mathrm{O}$ in position 2 and 4 and $\mathrm{N}$ in position 3 of the coumarin ring and $\mathrm{N}$ in position 1 of the thiazole) and one hydrogen bond acceptor/donor (the third $\mathrm{N}$ in position 2 of the thiazole). There are two rotatable bonds in all three compounds and zero stereo-centers.

According to the predicted $\mathrm{p} K_{\mathrm{a}}$ values and solubility profile (Table III), conjugate acids of investigated compounds are dibasic weak acids. The first $\mathrm{p} K_{\mathrm{a}}$ value, the value around 4 experimentally obtained by the two methods, is similar to the predicted one. The protonation site in the molecule of investigated compounds is most probably carbonyl oxygen (oxygen in position 2). As regards the second $\mathrm{p} K_{\mathrm{a}}$ value, it cannot be concluded from the appearance of the UV spectra that a second protonation occurs. However, when analyzing the shape of the protonation " $\mathrm{S}$ " curve in the $\mathrm{pH}$ range $2.5-1$, i.e., the dependence on the maximum absorbance of the absorption band at higher wavelengths originating from the thiazole ring, one could assume that the eventual second $\mathrm{p} K_{\mathrm{a}}$ value is around 1.5. It indicates that the second protonation site would be a nitrogen atom in the thiazole ring. This cannot be confirmed or denied by $\mathrm{pH}$-metric titration because of restrictions in the $\mathrm{pH}$ range in which the $\mathrm{pH}$ meter is calibrated.

Water solubility of the synthesized compounds, expressed in $\log S_{\mathrm{w}^{\prime}}$ ranged from -3.80 to -3.46 and it was between -3.66 and -2.46 at the physiological $\mathrm{pH} 7.4$ (Table III). Although slight discrepancy was observed between the predicted and experimentally determined values for water solubility $\left(\log S_{\mathrm{w}}\right)$ and solubility at $\mathrm{pH} 7.4\left(\log S_{7.4}\right)$ (Table III), a high correlation was observed between them $(R=0.957$ and $R=0.994$, respectively) when a simple regression was performed. Among the synthesized compounds, the compound 3-[2-(1,3-thiazol-2-yl)hydrazinylidene]chroman-2,4-dione (1c) showed the highest water solubility and solubility at $\mathrm{pH} 7.4$.

The solubility, $\mathrm{p} K_{\mathrm{a}}$ and $\log D_{7.4}$ values determined experimentally for monobasic acid 4-HC were in accord with the literature data (28). In the $\mathrm{pH}$ region where $\mathrm{pH} \gg \mathrm{pK} K_{\mathrm{a}}$ (or $\mathrm{pH}$ $\left.>\mathrm{p} K_{\mathrm{a}}+1.5\right)$, the equation $\log D=\log P-\mathrm{pH}+\mathrm{p} K_{\mathrm{a}}$ holds and can be used to estimate the partition coefficient of the undissociated monobasic acid $(\log P)$ when the $\mathrm{p} K_{\mathrm{a}}$ value is al- 


\begin{tabular}{|c|c|c|c|c|c|c|c|c|c|}
\hline 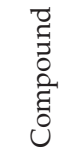 & $\Sigma^{4}$ & 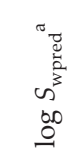 & 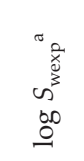 & 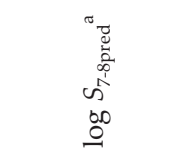 & 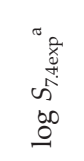 & 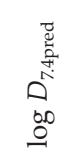 & 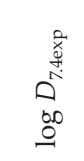 & 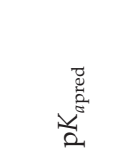 & 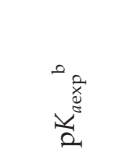 \\
\hline 4-HC & 162.14 & -0.81 & -2.53 & -0.45 to 0 & -1.41 & 1.03 & -0.61 & 5.3 & $4.12 / 4.19$ \\
\hline 1c & 273.27 & -3.48 & -3.46 & -1.71 to -0.71 & -2.46 & 3.30 & -0.10 & $4.58 ; 2.56$ & $4.23 / 4.30$ \\
\hline $1 d$ & 287.29 & -3.73 & -3.57 & -2.64 to -1.65 & -3.44 & 3.48 & 0.15 & $4.99 ; 2.87$ & $4.28 / 4.36$ \\
\hline 1e & 301.32 & -3.91 & -3.80 & -2.7 to -1.7 & -3.66 & 3.76 & 0.60 & $4.88 ; 2.83$ & $4.48 / 4.82$ \\
\hline
\end{tabular}

exp - experimental, pred - predicted, $\mathrm{w}$-water, aqueous

a Solubility in $\mathrm{mol} \mathrm{L}^{-1}$.

${ }^{\mathrm{b}} \mathrm{pH}-\mathrm{metric} / \mathrm{UV}$

ready known. $\log P$ of $4-\mathrm{HC}$ thus obtained was 2.63 , which is fairly close to the value of 2.37 determined by van der Giessen and Janssen (28). Experimentally determined distribution coefficients $\left(\log D_{7.4 \mathrm{exp}}\right)$ of the synthesized compounds ranged between -0.096 (1c) and 0.602 (1e). As shown in Table III, large discrepancy was noted between the experimentally obtained $\log D_{7.4 \exp }$ values and the predicted distribution coefficients $\log D_{7.4 p r e d}$. However, when performing a simple regression, a strong correlation between the predicted and experimental values $(R=0.999)$ was found. Discrepancy between the predicted and experimentally determined values for the distribution coefficients might be caused by the tautomeric behavior of the compounds. Possible tautomeric forms of the synthesized hydrazinyldiene-chroman-2,4-diones are presented in Scheme 1. As can be seen, the compounds may occur in keto and in enol form. The exact concentration of each tautomeric form is governed by the tautomeric equilibrium, which depends strongly on the medium and is therefore different for the aqueous and for the organic phase. This means that keto and enol forms may have different lipophilicity, which directly affects the measured distribution coefficient.

Obviously, introduction of methyl group(s) into the thiazole ring led to a decrease in water solubility and increase in lipophilicity, probably due to the inductive character of the methyl groups that disfavors ionization. This increase in lipophilicity can drastically modify the bioavailability, disposition and potency of these compounds. According to the literature data (29), in a number of cases, the gain in potency was more than 180 -fold and in all of them the methyl group reorganized the conformation of the ligand for optimal inter-
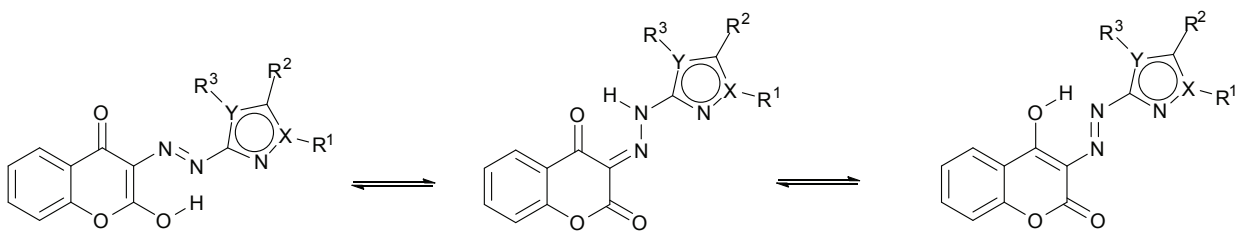

Scheme 1 
actions with the receptor. However, no significant difference in potency $\left(I C_{50}\right)$ between the synthesized compounds was observed in our study. This finding is consistent with the conclusions derived from the literature analysis performed by Leung et al. (30). Analysis of more than 2000 cases revealed that adding a methyl to a lead compound neither improved nor decreased affinity to the corresponding protein receptors. The authors concluded that to go beyond the 10 -fold increase in activity, besides placement of a methyl group in a hydrophobic environment, it is also necessary to induce a propitious conformational change. Therefore, further studies are needed to deduce how the compounds synthesized in our study interact with the receptors and also how they are absorbed and distributed on their way to the receptors.

\section{CONCLUSIONS}

Hydrazinyldiene-chroman-2,4-diones having thiazole moiety without or with additional methyl group(s) attached to the carbon(s) at position(s) 5 and/or 4 in the thiazole ring can effectively inhibit proliferation of MCF-7 cells, inhibit cell migration and induce chromatin condensation, DNA damage and caspase-dependent apoptosis, and arrest the cell cycle at the $\mathrm{G}_{2} / \mathrm{M}$ stage. In the presence of Doxo, the potency of these compounds increases. With their solubility profile and $\log D_{7.4}$, all three compounds follow Lipinski's rule of five for good permeability (absorption) potential, $\log D_{7.4}$ less than 5 , molecular mass less than 500 $\mathrm{Da}$, fewer than 5 hydrogen bond donors and fewer than 10 hydrogen bond acceptors. The coumarin derivative 3-[2-(4,5-dimethyl-1,3-thiazol-2-yl)hydrazinylidene]chroman2,4-dione (1e) shows the lowest water solubility at $\mathrm{pH}$ 7.4, highest lipophilicity and slightly higher potency than the other derivatives, without or with one methyl group attached to the thiazole moiety in position 4 . Further studies are needed to determine their permeability and transport interactions, pharmacokinetic properties and exact mechanisms of action.

Acknowledgements. - The authors express their gratitude to Andrea Huwiler and the Institute of Pharmacology at the University of Bern, Switzerland, for cooperation in cellular characterization of the synthesized coumarin derivatives.

List of acronyms, symbols and codes. - A375 - human melanoma cell line, A549 - human lung cancer cell line, B16 - murine melanoma cell line, Bax - Bcl-2-associated X protein, Bcl-2 - B-cell lymphoma 2 protein, Bcl-xL - B-cell lymphoma-extra-large protein, CaMK II - calcium/calmodulin-dependent protein kinase II, Cdc2 kinase - cyclin-dependent protein kinase Cdk1/Cdc2, Cdk - cyclin-dependent kinase, CRL 1548 - rat liver cancer line, DDIT4 - DNA damage inducible transcript 4, DMEM - Dulbesco's modified Eagle's medium, Doxo - doxorubicin, FADH - flavin adenine dinucleotide, FBS - fetal bovine serum, FMNH - semiquinone form of flavin mononucleotide, FoxM1 - Forkhead Box M1, GAPDH glyceraldehyde-3-phosphate dehydrogenase, Hct-116 - human colon carcinoma cell line, HepG2 - human liver cancer cell line, IGFBP5 - insulin like growth factor binding protein 5, LRP8 - LDL receptor related protein 8 , MAPK - ATP $\mathrm{p}^{38}$ mitogen activated protein kinase, MCF-7 - human breast adenocarcinoma cell line, MCF-7R - multidrug-resistant variant of MCF-7 cell line, MDA-MB-231 - human breast adenocarcinoma cell line, MTT -3-(4,5-dimethylthiazol-2-yl)-2,5-diphenyltetrazolium bromide, NADH - nicotinamide adenine dinucleotide, NADPH - nicotinamide adenine dinucleotide phosphate, P388 - mouse leukemia cells, PARP - poly (ADP-ribose) polymerase, PDGFRA - platelet derived growth factor receptor alpha, Phospho-Thr ${ }^{308} \mathrm{Akt}$ - protein kinase Akt phosphorylated at threonine 308, PI propidium iodide, PI3K-AKT-mTOR - phosphatidylinositol-3-kinase-Akt-mammalian target of rapamycin, PMSF - phenylmethylsulfonyl fluoride, SCP1833 - bone metastatic cell line from breast cancer, SCP4175 - lung metastatic cell line from breast cancer, Skp2 - S-phase kinase-associated protein 2, STAT3 - signal transducer and activator of transcription 3. 
L. Ballazhi et al.: Hydrazinyldiene-chroman-2,4-diones in inducing growth arrest and apoptosis in breast cancer cells: Synergism with doxorubicin and correlation with physicochemical properties, Acta Pharm. 67 (2017) 35-52.

\section{REFERENCES}

1. A. M. Stuckey, Breast cancer: epidemiology and risk factors, Clin. Obst. Gynecol. 54 (2011) 96-102; DOI: $10.1097 / G R F .0 b 013 e 3182080056$.

2. F. C. Thorn, C. Oshiro, S. Marsh, T. Hernandez-Boussard, H. McLeod, T. Klein and B. R. Altman, Doxorubicin pathways: pharmacodynamics and adverse effects, Pharmacogenet. Genom. 21 (2011) 440-446; DOI: 10.1097/FPC.0b013e32833ffb56.

3. A. Jashari, F. Imeri, L. Ballazhi, A. Shabani, B. Mikhova, G. Dräger, E. Popovski and A. Huwiler, Synthesis and cellular characterization of novel isoxazolo- and thiazolohydrazinyldiene-chroman-2,4-diones on cancer and non-cancer cell growth and death, Bioorg. Med. Chem. 22 (2014) 2655-2661; DOI: 10.1016/j.bmc.2014.03.026.

4. S. Chen, M. Cho, K. Karlsberg, D. Zhou and Y. Yuan, Biochemical and biological characterization of a novel anti-aromatase coumarin derivative, J. Biol. Chem. 279 (2004) 48071-48078; DOI: 10.1074/ jbc.M406847200.

5. L. Woo, A. Purohit, B. Malini, M. Reed and B. Potter, Potent active site-directed inhibition of steroid sulphatase by tricyclic coumarin-based sulphamates, Chem. Biol. 7 (2000) 773-791; DOI: 10.1016/S1074-5521(00)00023-5.

6. M. Musa, J. Cooperwood and M. Khan, A review of coumarin derivatives in pharmacotherapy of breast cancer, Curr. Med. Chem. 15 (2008) 2664-2679; DOI: 10.2174/092986708786242877.

7. S. Kirkiacharian, A. Lormier, H. Chidiack, F. Bouchoux and E. Cérède, Synthesis and binding affinity to human alpha and beta estrogen receptors of various 7-hydroxycoumarins substituted at 4- and 3,4- positions, Farmaco 59 (2004) 981-986; DOI: 10.1016/j.farmac.2004.08.004.

8. M. Halasi, H. Zhao, H. Dahari, U. G. Bhat, E. B. Gonzalez, A. V. Lyubimo, D. A. Tonetti and A. L. Gartel, Thiazole antibiotics against breast cancer, Cell Cycle 9 (2010) 1214-1217; DOI: 10.4161/ cc.9.6.10955.

9. J. Shaw, B. Chen, J. P. Bourgault, H. Jiang, K. Narendra, M. Jayshree, A. V. Frederick, M. Joe, B. Kevin, P. Halina, E. Matthew and R. A. Peter, Synthesis and biological evaluation of novel nphenyl-5-carboxamidyl isoxazoles as potential chemotherapeutic agents for colon cancer, Am. J. Biomed. Sci. 4 (2012) 14-25; DOI: 10.5099/aj120100014.

10. P. Poma, M. Notarbartolo, M. Labbozzetta, A. Maurici, V. Carina, A. Alaimo, M. Rizzi, D. Simoni and N. D'Alessandro, The antitumor activities of curcumin and of its isoxazole analogue are not affected by multiple gene expression changes in an MDR model of the MCF-7 breast cancer cell line: analysis of the possible molecular basis, Int. J. Mol. Med. 20 (2007) 329-335; DOI: 10.3892/ ijmm.20.3.329.

11. L. Ballazhi, E. Popovski, A. Jashari, F. Imeri, I. Ibrahimi, B. Mikhova and K. Mladenovska, Potential antiproliferative effect of isoxazolo- and thiazolo coumarin derivatives on breast cancer mediated bone and lung metastases, Acta Pharm. 65 (2015) 53-63; DOI: 10.1515/acph-2015-0002.

12. A. Jashari, E. Popovski, B. Mikhova, P. R. Nikolova and L. B. Shivachev, 3-[2-(5-tert-Butyl-1,2-oxazol-3-yl)hydrazinylidene]chroman-2,4-dione, Acta Crystallogr. E69 (2013) o258; DOI: 10.1107/ S1600536813000858.

13. L. Ballazhi, F. Imeri, A. Dimovski, A. Jashari, E. Popovski, P. B. Selmani, B. Mikhova, G. Dräger, E. Alili-Idrizi and K. Mladenovska, Synergy of novel coumarin derivatives and tamoxifen in blocking growth and inducing apoptosis of breast cancer cells, Mac. Pharm. Bull. 60 (2014) 35-44.

14. N. C. Bols, V. R. Dayeh, L. E. J. Lee and K. Schirmer, Use of Fish Cell Lines in the Toxicology and Ecotoxicology of Fish, in Biochemistry and Molecular Biology of Fishes - Environmental Toxicology (Eds. T. P. Mommsen and T. W. Moon), Vol. 6, Elsevier Science, Amsterdam 2005, pp. 43-84.

15. R. Hamid, Y. Rotshteyn, L. Rabadi, R. Parikh and P. Bullock, Comparison of alamar blue and MTT assays for high through-put screening, Toxicol. In Vitro 18 (2004) 703-710; DOI: 10.1016/j. tiv.2004.03.012. 
16. W. F. Deckert and K. H. Remmer, In vitro inhibition of rat and human liver microsomal enzymes by 4-hydroxycoumarin anticoagulants and related compounds, Chem. Biol. Inter. 5 (1972) 255-263; DOI: 10.1016/0009-2797(72)90029-4.

17. H. Liu, Y. Wang, A. Sharma, R. Mao, N. Jiang, B. Dun and X. J. She, Derivatives containing both coumarin and benzimidazole potently induce caspase-dependent apoptosis of cancer cells through inhibition of PI3K-AKT-mTOR signaling, Anticancer Drugs 26 (2015) 667-677; DOI: 10.1097/ CAD.0000000000000232.

18. O. Bar-On, M. Shapira and D. D. Hershko, Differential effects of doxorubicin treatment on cell cycle arrest and Skp2 expression in breast cancer cells, Anti-Cancer Drugs 18 (2007) 1113-1121; DOI: 10.1097/CAD.0b013e3282ef4571.

19. R. Lüpertz, W. Wätjen, R. Kahl and Y. Chovolou, Dose- and time-dependent effects of doxorubicin on cytotoxicity, cell cycle and apoptotic cell death in human colon cancer cells, Toxicology 271 (2010) 115-121; DOI: 10.1016/j.tox.2010.03.012.

20. A. M. Musa, L. V. Badisa, M. L. Latinwo, J. Cooperwood, A. Sinclair and A. Abdullah, Cytotoxic activity of new acetoxycoumarin derivatives in cancer cell lines, Anticancer Res. 31 (2011) 20172022.

21. A. Goel, K. A. Prasad, S. V. Parmar, B. Ghosh and N. Saini, 7,8-Dihydroxy-4-methylcoumarin induces apoptosis of human lung adenocarcinoma cells by ROS-independent mitochondrial pathway through partial inhibition of ERK/MAPK signaling, FEBS Lett. 581 (2007) 2447-2454; DOI: 10.1016/j.febslet.2007.04.052.

22. D. Alesiani, R. Cicconi, M. Mattei, C. Montesano, R. Bei and A. Canini, Cell cycle arrest and differentiation induction by 5,7-dimethoxycoumarin in melanoma cell lines, Int. J. Oncol. 32 (2008) 425-434; DOI: 10.3892/ijo.32.2.425.

23. F. Haghighi, M. M. Matin, A. R. Bahrami, M. Iranshahi, F. B. Rassouli and A. Haghighitalab, The cytotoxic activities of 7-isopentenyloxycoumarin on 5637 cells via induction of apoptosis and cell cycle arrest in G2/M stage, DARU J. Pharm. Sci. 22 (2014) Article ID: 3 (10 pages); DOI: 10.1186/20082231-22-3.

24. C. Barthomeuf, S. Lim, M. Iranshahi and P. Chollet, Umbelliprenin from Ferula szowitsiana inhibits the growth of human M4Beu metastatic pigmented malignant melanoma cells through cell-cycle arrest in G1 and induction of caspase-dependent apoptosis, Phytomedicine 15 (2008) 103-111; DOI: 10.1016/j.phymed.2007.04.001.

25. Y. J. Chuang, F. Y. Huang, F. H. Lu, C. H. Ho, S. J. Yang, M. T. Li, W. N. Chang and G. J. Chung, Coumarin induces cell cycle arrest and apoptosis in human cervical cancer HeLa cells through a mitochondria- and caspase-3 dependent mechanism and NF-kappaB down-regulation, In Vivo 21 (2007) 1003-1010.

26. M. Kielbus, K. Skalicka-Wozniak, A. Grabarska, W. Jeleniewicz, M. Dmoszynska-Graniczka, A. Marston, K. Polberg, P. Gawda, J. Klatka and A. Stepulak, 7-Substituted coumarins inhibit proliferation and migration of laryngeal cancer cells in vitro, Anticancer Res. 33 (2013) 4347-4356.

27. D. Yang, T. Gu, T. Wang, Q. Tang and C. Ma, Effects of osthole on migration and invasion in breast cancer cells, Biosci. Biotechnol. Biochem. 74 (2010) 1430-1434; DOI: 1271/bbb.100110.

28. W. F. van der Giesen and L. H. Janssen, Influence of ionization and ion-pair formation on lipophilicity of some 4-hydroxy-coumarin derivatives in the octanol-water system, Int. J. Pharm. 12 (1982) 231-249; DOI: 10.1016/0378-5173(82)90122-3.

29. H. Schönherr and T. Cernak, Profound methyl effects in drug discovery and a call for new C-H methylation reactions, Angew. Chem. Int. Ed. Engl. 52 (2013) 12256-12267; DOI: 10.1002/ anie.201303207.

30. S. C. Leung, S. S. Leung, J. R. Tirado and L. W. Jorgensen, Methyl effects on protein-ligand binding, J. Med. Chem. 55 (2012) 4489-4500; DOI: 10.1021/jm3003697. 